\title{
The identification of soil fungi isolated from rhizosphere in different varieties of jali (Coix lacryma-jobi) in Loa Kulu, Kutai Kartanegara, Indonesia
}

\author{
SOPIALENA ${ }^{1, \bullet}$, N. AKHSAN ${ }^{1}$, A. SURYADI ${ }^{1}$, JULI NURDIANA ${ }^{2, v \vee}$ \\ ${ }^{1}$ Department of Agroecotechnology, Faculty of Agriculture, Universitas Mulawarman. Jl. Pasir Belengkong, Kampus Gunung Kelua, Samarinda 75119 , \\ East Kalimantan, Indonesia. Tel.: +62-541-749161, Fax.: +62-541-738341."email: sopialena88@gmail.com \\ ${ }^{2}$ Environmental Engineering Study Program, Faculty of Engineering, Universitas Mulawarman. Jl. Sambaliung No. 9, Kampus Gunung Kelua, \\ Samarinda 75117, East Kalimantan, Indonesia. Tel.: +62-541-749315, Fax.: +62-541-736834. "•email: julinurdiana@ gmail.com
}

Manuscript received: 19 September 2018. Revision accepted: 22 November 2018

\begin{abstract}
Sopialena, Akhsan N, Suryadi A, Nurdiana J. 2018. The identification of soil fungi isolated from Rhizosphere in different varieties of jali plants (Coix lacryma-jobi) in Loa Kulu, Kutai Kartanegara, Indonesia. Asian J Agric 2: 44-47. Rhizosphere effects can indicate the development of an active microbial population around the roots, driving from a loss of organic materials. This research was intended to identify rhizosphere microbes by identifying the potential microbes of four different varieties of jali (Coix lacryma-jobi L.) in Loh Sumber, Loa Kulu, Kutai Kartanegara, Indonesia, i.e., jelai beras, jelai ketan, ketan lekat, and jelai kaltara. The soil samples were collected and isolated in a jali plantation in Loa Kulu, Kutai Kartanegara at 45 days after planting. As many as 16 isolated samples were used, collected from four different varieties of jali and replicated 4 times. The results showed that a variety of microbes at Rhizosphere could be classified as Trichoderma sp., Aspergillus sp., Pythium sp., Fusarium sp., Cunninghamelal sp., and Penicillium sp.
\end{abstract}

Keywords: Rhizosphere, jali, Coix lacryma-jobi, fungus, Indonesia

\section{INTRODUCTION}

In Indonesia, the commodity of jali (Coix lacryma-jobi L.) can be found in Sumatra, Java and Kalimantan. However, to date, it has not been widely developed in East Kalimantan (Juliardi et al. 2014). Based on the information collected, there are more than one varieties of jali cultivated in East Kalimantan, namely (i) jelai beras (padi jelai sumber rejeki I), (ii) jelai ketan (padi jelai sumber rejeki II), (iii) ketan lekat (padi jelai sumber rejeki III), and the variety of jelai kaltara (Suyadi 2011). Rhizosphere is the part of the soil surrounding the roots and serves as a first layer defense for pathogens (Nurbailis et al. 2014). Some rhizosphere microorganisms, have proven to play an important role in nutrient cycling, soil formation, plant growth, microorganism activities and acting as a biological control against the pathogens surrounding the plant roots. The benefits of a microbial population around the rhizosphere include maintaining the nutrient intake for the plant (Budiarti et al. 2014).

In general, there are two types of microorganisms living in the rhizosphere; microbial antagonists and pathogenic microbes (Beneduzi et al. 2012; Trabelsi and Mhamdi 2013; Barea 2015). Antagonists microorganisms commonly found in the root zone, include Trichoderma, Aspergillus, and Penicillium. While pathogenic microorganisms are mostly found as Phytophthora, Pythium, and Fusarium which can reduce plant production, thus ultimately impact on the loss of productivity. Therefore, this study aimed to identify the rhizosphere microorganism in jali's at the village of Loh Sumber, Loa Kulu District of Kutai
Kartanegara. The function of this research is to know the types of rhizosphere fungi living in the four types of jali. Though jali is commonly known as fodder, it often is used by malt producer, and serves as kind of health food. Nowadays, there is an attempt to utilize and cultivate jali is some part of Indonesia, included in the village Loh Sumber, Loa Kulu (Badan Ketahanan Pangan dan Penyuluhan 2016).

Microorganisms living in the rhizosphere have a vital role in maintaining soil fertility because of their ability as decomposers. Some microorganisms that live at the roots of healthy plants are known to be protective against pathogens. Naturally, they can hamper the development of pathogens in the soil. In addition, the ability of the organism to adapt to various environmental conditions has great potential for them, allowing them to serve as a biological control agent. Rizospheric fungi are among the groups of microorganisms that have been reported to induce plant resistance to various diseases, including ground-borne diseases. They also support the growth of the plant through various mechanisms such as increasing nutrient uptake, biological control of pathogens, and producing the hormone for the plants (Pereg and McMillan 2015; Jacoby et al. 2017).

The concept of rhizospheres, was first proposed by Hiltner in 1904 (Larry et al. 2016). The population of microorganisms in the rhizosphere is usually more numerous and varied than in the non-rhizosphere zones. Rhizosphere soil affected the roots and substances released from the roots into the soil solution, to create favorable conditions for fungi. The presence of antagonistic 
microorganisms in the rhizosphere can inhibit the spread and root infection by pathogens, a condition referred to as a natural microbial barrier (Rodrigo et al. 2013; de Boer et al. 2015). The main biological facts of rhizosphere, or rootaffected areas, are the high number and high activity of soil microorganisms in this area compared to rootless soils (Fety et al. 2015; Suyadi et al. 2017). As biological control agents, the antagonist microorganisms will detain the spreading of the pathogens. This situation is natural and a microbial barrier, this microbial antagonist is potentially developed as a biological control agent (Gusnawaty et al. 2014). In the rhizosphere, it is suggested that there are harmful organisms around the roots of unhealthy plants. While on the other hand, it is found that beneficial organisms live at the roots of healthy plants. It is reported that the fungi of the genus Trichoderma and Gliocladium, are antagonistic fungi that often can be found in the area of the rhizosphere (Nurbailis et al. 2014). The results of research showed 8 fungal isolates from the potato plant rhizosphere, consisting of two isolates of Trichoderma genus, one Penicillium isolate, two Phytophthora isolates, one Mucor isolates and two isolates unknown to its genus (Budiarti and Nurhayati 2014). The rhizosphere effect indicated the development of active microbial population around the roots driving from the loss of organic materials. Considering the rhizosphere effects, this research aimed to identify the available potential microbes at different four varieties of jali (Coix lacryma-jobi L.) in Loa Kulu, Kutai Kartanegara, Indonesia. Even though there are many discussions around microbes and the rhizosphere, this study can bring scientific value in terms of the identification of microbes for jali in Loa Kulu which has not been previously explored.

\section{MATERIALS AND METHODS}

This research was conducted between May to August 2017 in jali cultivation areas; Loh Sumber village, Loa Kulu, Kutai Kartanegara. The soil sampling was collected 45 days after planting by drilling, to reach a depth of $30 \mathrm{~cm}$ with $10 \mathrm{~cm}$ distance from the planting hole. There were 5 sample points taken by zigzag pattern, which then were composited into $1 \mathrm{~kg}$ mixture, and then composited for a second time into $100 \mathrm{~g}$ ( 1 ounces). The total samples used were 16 pieces, consisting of 4 samples of each variety and 4 replications.

To identify the isolated fungi, the soil sample of four different varieties of jali was firstly weighed at $1 \mathrm{~g}$, and then inserted into a test tube containing $10 \mathrm{ml}$ of sterile distilled water and then shaken. From the solution, $1 \mathrm{ml}$ was taken and put into a test tube containing $9 \mathrm{ml}$ of sterile aquadest. This process kept recurring until it reached a 10-3 dilution level of cpu (cell per unit). From the dilution, $1 \mathrm{ml}$ was taken and then injected into the petri dish which had been filled with Potato Dextrose Agar (PDA) and isolated for 3-7 days at a room temperature of $27-28^{\circ} \mathrm{C}$. Later, a direct observation using the microscope was performed to identify the fungal colonies taken by an ose of the needle and adding it with a methylene blue liquid. The purification process was carried out to fungal colonies. For each different fungi, it was taken and re-grown on a petri dish containing solid PDA. The fungi identification was then referred to Alexopoulus and Mims (1979) and Samson and van Reenen-Hoekstra (1988) using an Optilab camera.

\section{RESULTS AND DISCUSSION}

Rhizosphere is part of the soil that has the highest metabolic activity defined as a small portion of the soil volume, which is directly affected by the growth and metabolism of plant roots. Plants and microbes interact and stimulate each other, this is caused by root exudates (Hunter et al. 2014). Where root exudates affect the growth and activity of microorganisms in the Rhizosphere, Rhizoplan, and its surroundings. Various types of microorganisms inhabit the rhizosphere such as fungi, bacteria, actinomycetes, algae, and nematodes. The activity of microorganisms in the rhizosphere and rhizoplane is different from the surrounding soil, depending on the root exudate released. In this regard, this study identified the fungal activity in the rhizosphere to characterize the type of fungal microbes for specific plants and certain geographic areas.

Based on the field information collected, this research classified the different varieties of isolated fungi rhizosphere based on jali's varieties and the replication from Jelai Beras, Jelai Ketan, Ketan Lekat and Jelai Kaltara. The results were presented in Table 1,.

The findings in Table 1 clearly show that in the $1^{\text {st }}, 2^{\text {nd }}$ and $4^{\text {th }}$ replication, the rhizosphere fungi of four different varieties of jali can be grouped as Trichoderma sp., Aspergillus sp. and Pythium sp. Only in the $3^{\text {rd }}$ replication, was a more varied fungus shown, i.e., Trichoderma sp. (Figure 1.A-B), Aspergillus sp. (Figure 2.A-B), Pythium sp. (Figure 3.A-B), Fusarium sp. (Figure 4.A-B), Cuninghamella sp. (Figure 5.A-B), and Penicillium sp. (Figure 6.A-B). This finding suggests that more fungi can live in jali's rhizosphere. Meanwhile, Anggraeni and Usman (2015) identified that Trichoderma sp. and Aspergillus sp. were also mostly found in Banana's rhizosphere. It is suggested that the different variety and characteristics of the fungus depend on many factors including substrate and environmental conditions (SuttonGrier et al. 2011; Haleem Khan and Karuppayil 2012; Basu et al. 2015).

Table 1. Name of fungi isolated from rhizosphere in different varieties of jali.

\begin{tabular}{lclll}
\hline Name of jali's varieties & \multicolumn{4}{c}{ Number of replication } \\
& $\mathbf{1}^{\text {st }}$ & $\mathbf{2}^{\text {nd }}$ & $\mathbf{3}^{\text {rd }}$ & $\mathbf{4}^{\text {th }}$ \\
\hline Jelai beras & 1,2 & 1,2 & 2,3 & 1,2 \\
Jelai ketan & 1,3 & 1,3 & $1,2,5$ & 1,2 \\
Ketan lekat & 1,2 & $1,2,3$ & $1,2,4$ & $1,2,3$ \\
Jelai Kaltara & 1,3 & 1,2 & $1,2,6$ & $1,2,3$ \\
\hline
\end{tabular}

Note: 1. Trichoderma sp., 2. Aspergillus sp., 3. Pythium sp., 4. Fusarium sp., 5. Cunninghamella sp., 6. Penicillium sp. 
Substrate is the main source of nutrients for fungi. New nutrients can be utilized after the fungus excretes extracellular enzymes that can break down the complex compounds from the substrate into more simple compounds. Fungi that cannot produce enzymes, according to substrate composition by themselves cannot utilize the nutrients in the substrate (Fety et al. 2015). While the environmental conditions that affect the presence of fungi, include moisture and temperature (Suyadi 2011; Suyadi et al. 2017). In addition, humidity is also very important for fungi growth. In general, fungi such as Aspergillus, Penicillium, Fusarium, and many other Hyphomycetes can live in lower relative humidity. A good temperature for fungus growth is very influential. Most fungi, including mushrooms, have a mesophilic temperature which allows them to grow at the optimum temperature between $25-35^{\circ} \mathrm{C}$ (Kapoor and Sharm 2014). Even so, it is also noted that there are thermophilic fungi that are able to grow at high temperatures (Saroj et al. 2017). Identifying the temperature range of the fungus growth is very important,

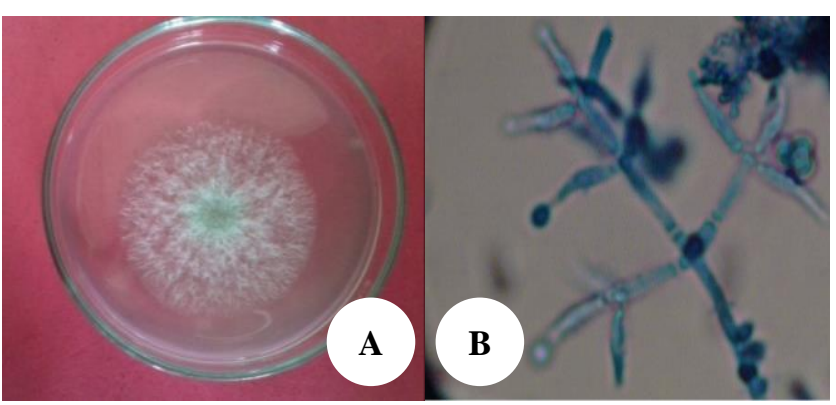

Figure 1. Trichoderma sp.

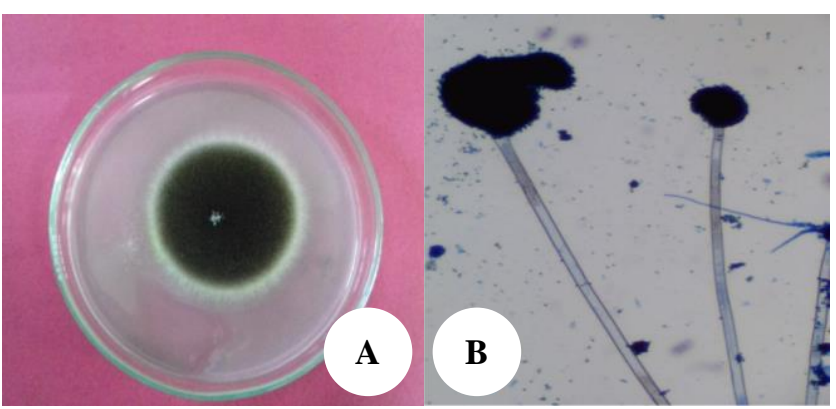

Figure 2. Aspergillus sp.

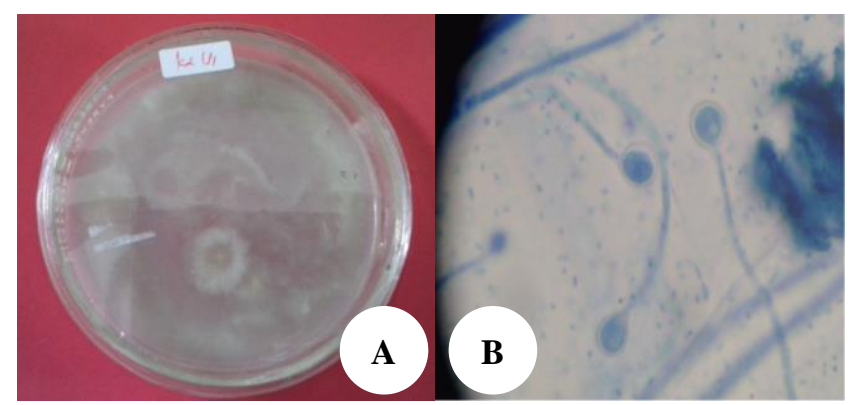

Figure 3. Pythium sp. in order to have a supportive environment for the fungus (Singh and Chauchan 2013; Lene 2014).

The results of this study supported the research conducted by Sopialena et al. (2017) which identified that besides Rhizoctonia, Phytium sp., Penicillium sp., Aspergillus sp., have become the four main types of fugal which are often found in East Kalimantan, particularly in post-coal-mining areas. Also, two other types of fungal were located; Cuninghamella sp. and Trichoderma sp. Aspergillus sp. and Fusarium sp. seems to be dominated in East Kalimantan, in particular for Kutai Kartanegara (Sopialena et al, 2018). Further, Rosfiansyah, et al. (2017) also noticed that likewise Massarina sp. and Rhizoctonia sp., Phytium sp., and Penicillium sp. retain potential value as biofertilizer for land reclamation in post-coal mining areas in Samarinda. Therefore, this study deepens the knowledge of fungal inventory observed in East Kalimantan land that only a limited number of fungal found on the soil, mainly due to the climatic conditions i.e., rainfall and temperature, and the type of soil which is dominated by red yellow podzolic.

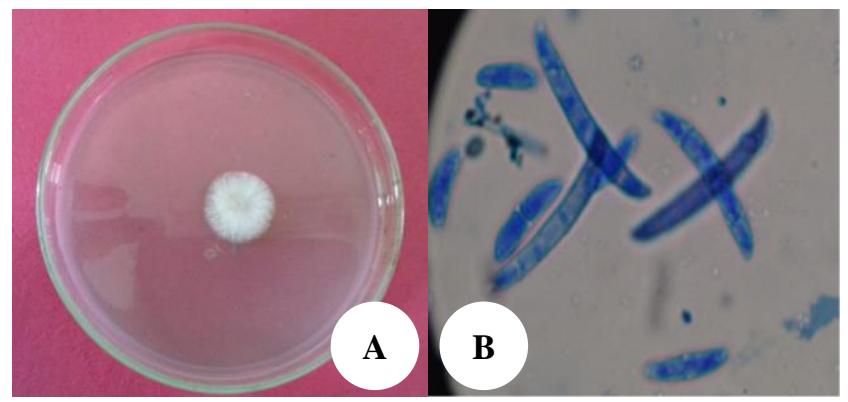

Figure 4. Fusarium sp.

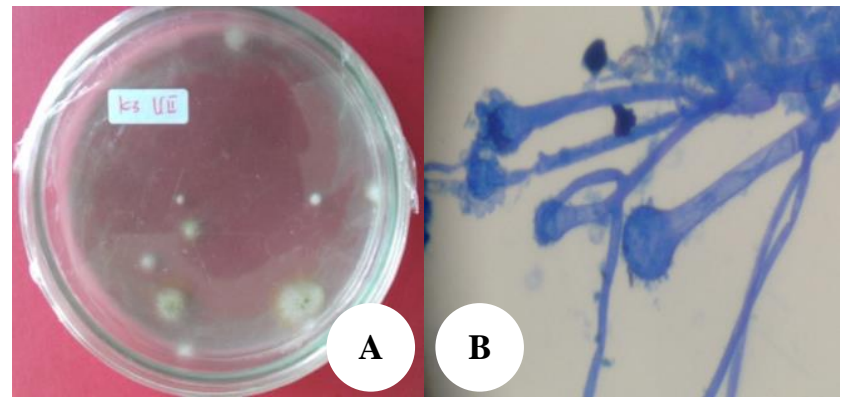

Figure 5. Cuninghamella sp.

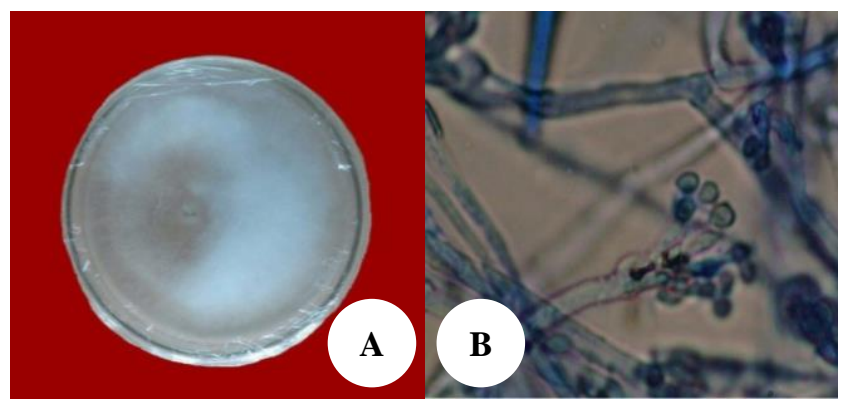

Figure 6. Penicillium sp. 
In regard to the climate condition of Kutai Kartanegara area, the average monthly rainfall is recorded at 259.8 $\mathrm{mm} / \mathrm{month}$, which suggests becoming the main reason for the wet/ humid condition of the subsurface soil. This condition is advised to have significant effect on soil microorganism activities, the speed of chemical synthesis, and the soil nutrients due to percolation and lessivation of water (Sopialena and Pratiwi 2017). Heavy rainfall has a significant impact on kinetic energy, which may cause changes in the composition and size of soil particles. Further, the run-off water on the soil surface may generate erosion and material translocation, in particular for areas where the level of cover is ruined. High rainfall causes inundation or flooding in some flat areas. In addition, the slight difference in range temperature from day to night, may also affect the organism decomposition process, which is shown from the low rate of soil macro contents such as $\mathrm{N}, \mathrm{P}$ and $\mathrm{K}$.

In conclusion, this study brought a new finding of rhizosphere microbes of jali (Coix lacryma-jobi L.) in Loa Kulu, Kutai Kartanegara. It has expanded the knowledge on the identification of microbes in three different varieties of jali in East Kalimantan. The results indicate that there are six main fungi found at the rhizosphere, namely Trichoderma sp. Aspergillus sp., Pythium sp., Fusarium sp., Cunninghamella sp., and Penicillium sp.

\section{REFERENCES}

Alexopoulos CJ and Mums CW. 1979. Introductory Mycology $3^{\text {rd }}$ ed John Wiley and Sons, New York.

Anggraeni DN, Usman M. 2015. Uji aktivitas dan identifikasi jamur rhizosfer pada tanahperakaran tanaman pisang (musa paradisiaca) terhadapjamur fusarium. Biolink 1 (2): 89-98. [Indonesian]

Badan Ketahanan Pangan dan Penyuluhan Provinsi Kaltim. 2016. Budidaya Jelai. bkpp.kaltimProv.go.Id/tanaman jelai.

Barea JM. 2015. Future challenges and perspectives for applying microbial biotechnology in sustainable agriculture based on a better understanding of plant-microbiome interactions. J Soil Sci Plant Nutr 15 (2): 261-282.

Basu S, Bose C, Ojha N. 2015. Evolution of bacterial and fungal growth media. Bioinformation 11 (4): 182-184.

Beneduzi A, Ambrosini A, Passaglia LM. 2012. Plant growth-promoting rhizobacteria (PGPR): Their potential as antagonists and biocontrol agents. Genet Mol Biol 35 (4 (suppl)): 1044-1051.

Budiarti L, Nurhayati. 2014. Kelimpahan cendawan antagonis pada rhizosfer tanaman kacang panjang (Vigna sinensis (L.) Savi ex Hassk.). Proc. Seminar Nasional Lahan Suboptimal. [Indonesian]

de Boer W, Hundscheid MP, Klein GPJ, de Ridder-Duinen AS, Thion C, van Veen JA, van der Wal A. 2015. Antifungal rhizosphere bacteria can increase as response to the presence of saprotrophic fungi. PloS One 10 (9): e0137988. DOI: 10.1371/journal.pone.0094643.

Fety, Khotimah S, Mukarlina. 2015. Uji antagonis jamur rhizosfer isolat lokal terhadap Pythopthora sp. yang di isolasi dari batang langsat. J. Protobiont 4: 223-24. [Indonesian]

Gusnawaty HS, Taufik M, Triana L, Asniah. 2014. Karakterisasi morfologis Trichoderma spp. indigenus J Agroteknos 4: 87-93.
Haleem Khan AA, Mohan Karuppayil S. 2012. Fungal pollution of indoor environments and its management. Saudi J Biol Sci 19 (4): 405-426.

Hunter PJ, Teakle GR, Bending GD. 2014. Root traits and microbial community interactions in relation to phosphorus availability and acquisition, with particular reference to Brassica. Front Plant Sci 5: 27. DOI: $10.3389 /$ fpls.2014.00027.

Jacoby R, Peukert M, Succurro A, Koprivova A, Kopriva S. 2017. The role of soil microorganisms in plant mineral nutrition-current knowledge and future directions. Front Plant Sci 8: 1617. DOI: 10.3389/fpls.2017.01617.

Juliardi, Hartanto R, Warji, Budianto. 2014. Uji kinerja mesin perontok biji jali (Coix lacryma jobi L.) tipe rubber roll. J Teknik Pertanian Lampung 2: 185-194.

Kapoor P, Sharm BM. 2014. Studies on different growth parameters of Ganoderma lucidum. Intl J Sci Environ Technol 3 (4): 1515-1524.

Larry MY, Andrea C, Sacha JM, Karl R, Malcolm JB. 2016. The holistic rhizosphere: integrating zones, processes, and semantics in the soil influenced by roots. J Exp Bot 67 (12): 3629-3643

Lene L. 2014. The importance of fungi and mycology for addressing major global challenges. IMA fungus 5 (2): 463-71.

Nurbailis, Martinus, Azniza V. 2014 Keanekaragaman jamur pada rhizosfer tanaman cabai sistem konvensional dan potensinya sebagai agen pengendali hayati Colletotrichum gloeosporioides. J HPT Tropika 14 (1): 16-24. [Indonesian]

Pereg L, McMillan M. 2015. Scoping the potential uses of beneficial microorganisms for increasing productivity in cotton cropping systems. Soil Biol Biochem 80: 349-358.

Rodrigo M, Paolina G, Jos MR. 2013. The rhizosphere microbiome: significance of plant beneficial, plant pathogenic, and human pathogenic microorganisms. FEMS Microbiol Rev 37: 634-663.

Rosfiansyah, Sopialena, SuryaSila. 2017. Inventarisasi cendawan mikro serta potensinya sebagai biofertilizer dan agensia pengendali hayatipada lahan reklamasi tambang batu bara di Samarinda. Agrifor 14 (2): 273-285.

Samson RA, Reenen-Hoekstra ES. 1988. Introduction to food Borne Fungi $3^{\text {rd }}$ ed. Baarn. Centraallbureau voor Schimmelcultures.

Saroj A, Hemant S, Bhanu PP, Naveen K. 2017. Isolation and screening of thermophilic and thermotolerant fungi for production of hemicellulases from heated environments. Mycology 8 (3): 125-134.

Singh P, Chauhan M. 2013. Influence of environmental factors on the growth of building deteriorating fungi: Aspergillus flavus and Penicillium chrysogenum. Intl J Pharm Sci Res 4 (1): 425-429.

Sopialena, Pratiwi JP. 2017. Study of climatic factors on the population dynamics of Pyricularia oryzae on some varieties of paddy rice (Oryza sativa). Biodiversitas 18 (2): 701-708.

Sopialena, Rosfiansyah, Sila S. 2017. The benefit of topsoil and fertilizer mixture to improve the ex-coal mining land. Nusantara Biosci 9: 3643.

Sopialena, Suyadi, Sahil M, Nurdiana J. 2018. The diversity of endophytic fungi associated with Piper nigrum in the tropical areas: a recent study from Kutai Kartanegara, Indonesia. Biodiversitas 19 (6): 20282034.

Sutton-Grier AE, Wright JP, McGill BM, Richardson C. 2011. Environmental conditions influence the plant functional diversity effect on potential denitrification. PLoS ONE 6 (2): e16584. DOI: 10.1371/journal.pone.0016584.

Suyadi, Sopialena, Nurdiana J, Suryadi A, Rosfiansyah, Waluyo S. 2017. Genus Nematoda entomoparogen pada lahan lebak padi sawah (Oriza sativa L.) di Kecamatan Muara Wis, Kabupaten Kutai Kartanegara. Proceeding of Konferensi antarbangsa Islam Borneo. Mulawarman University, Samarinda, 25 September 2017. [Indonesian]

Suyadi. 2011. Potensi Jelai (Kaltim) atau Hanjeli (Jawa) sebagai Tanaman Pangan dan Obat obatan. Mulawarman University, Samarinda. [Indonesian]

Trabelsi D, Mhamdi R. 2013. Microbial inoculants and their impact on soil microbial communities: a review. BioMed Res Intl 2013: 863240. DOI: $10.1155 / 2013 / 863240$. 